\title{
Making Decisions About Decision-Making: Conscience, Regulation and the Law
}

\section{Introduction}

The exercise of medical conscience can have far-reaching and potentially fatal effects. Whether it is, as described below, a murderous doctor such as Harold Shipman whose moral code is so warped that he considers killing his patients a morally acceptable act, or the staff at Staffordshire whose consciences seemed to accept falling standards, the consequence was that people died. Whether and how doctors choose to act is therefore an issue of vital importance. This article will address the issue of the separation of the institutional, personal and professional ethical standards involved in interactions between doctor and patient. This area is of particular importance given the failure of ethical standards highlighted by Robert Francis QC in his report into the events at Staffordshire Foundation NHS Trust. ${ }^{1}$ The paper will explore the nature of each of the standards, their relationships with each other and the appropriateness of doctors having to choose between their professional obligations and their consciences. It will also assess how this categorisation might influence issues surrounding regulation and ensuring patients' rights are protected. Finally, the paper will examine the role of the law with respect to the proper protection of both the rights of patients and the need for doctors' choices based on their consciences to be respected.

Jonathan Montgomery, whose work pervades and informs much of this, and I agree on much. ${ }^{2}$ We both want to see decisions by doctors being made on a moral basis, and that morality being allowed to flourish. Law that is too prescriptive can indeed threaten to suffocate the very practice of that morality. However, our concern is not just that moral decisions are made, but instead that the right moral choices are arrived at. ${ }^{3}$ Put bluntly, neither of us wants Harold Shipman's morals being allowed the freedom to operate. Therefore, I would argue that it is vital that the conscience/morality of the doctor is limited in some way, so that we allow them to make the right choices but stop them from making the wrong ones. To this end, it follows that some limits can justifiably be put on the exercise of medical conscience, and some decisions can be taken out of medical hands altogether. We have to somehow ascertain how to ensure that

\footnotetext{
* I would like to thank the anonymous reviewers for their perceptive and helpful comments.

${ }^{1}$ Report of the Mid Staffordshire NHS Foundation Trust Public Inquiry - Executive Summary (HC 947, 2013).

${ }^{2}$ Indeed, his current views can be found in his article in this special edition.

${ }^{3}$ I do not here, for reasons of space, consider how exactly we can determine what a 'correct' moral or ethical choice is. Given this, I have used the obvious example of Harold Shipman, whose actions are clearly not within this category, to make the point in general terms.
} 
right rather than wrong choices are made. This will necessarily involve providing a mechanism by which choices might be made. This mechanism can come through the law, professional ethical guidance or indeed the personal morality of the individual medical practitioner. Here is where Montgomery and I might part company. I would argue that there is a role for medical ethics in fashioning a 'corporate morality' for the medical profession and saying that certain choices have to be made in certain ways if a person wishes to practice as a registered doctor. 'Moral' decisions are limited to ones where the doctor may legitimately choose any course of action amongst those considered moral. I discuss this further in the next section. This leads to two issues. First, it means that we are talking about two 'consciences' here - the conscience of the individual doctor, and that of the medical profession as a whole. Secondly, the difficulty lies in how we therefore categorise decisions as appropriately decided by the conscience of the doctor, that of the profession and its ethics or even by the law, which might create a third area of conscience where society removes decision-making power from the medical sphere altogether. The difficulty, of course, is ascertaining when each might be appropriate.

We must also consider the changes in the law in the context of the historical moment at which they occurred. Indeed legal change - and the amount of leeway we give to doctors and their morality - can be seen primarily as a reaction to what has recently happened. Thus, after the Second World War the prioritisation of autonomy was nothing if not an obvious response. Equally, Bolitho and de-Bolamisation can be seen as part of a process of recognising that a lot of the issues surrounding over deference to the medical profession needed to be addressed. 4 That said, such things are fundamentally cyclical, and just as we had Bolam and its rise after World War 2, we then saw in Bolitho a response to that. There is no doubt that, in the future, the cycle will continue and the law will once again seek to rebalance. ${ }^{5}$ In other words, we are now at a point where the legal and ethical response is likely to be one that is a response to instead of one that looks towards patient empowerment and the limitation of medical conscience and freedom. While this may help us to understand what goes on, it does not really aid in resolving it.

\section{Creating Room for Conscience}

We must begin, however, by justifying and defining the space within which the doctor's conscience should be permitted to operate. As I argue below, it is appropriate to place some limitations on decisions based on a doctor's individual

\footnotetext{
${ }^{4}$ Bolam v Friern Hospital Management Committee [1957] 1 WLR 582; Bolitho v City and Hackney Health Authority [1998] AC 232, HL

${ }^{5}$ A good example of this is the recently introduced Medical Innovation Bill, which argues that doctors are prevented from innovating by a fear of litigation. While this author would consider such fears to be misguided, it is supported by former Law Lords such as Lords Woolf and Mackay. Their speeches in the House of Lords debate demonstrate this point and can be found at http://www.theyworkforyou.com/lords/?id=2014-06-27a.1449.2 (last accessed $1^{\text {st }}$ October 2014).
} 
conscience (including morality and religious beliefs). Nevertheless, several reasons may be identified that suggest that it is clearly of benefit to allow medical professionals, in some cases at least, to act based on their consciences. The first and most important of these is that medical professionals are moral agents in their own right, and should be treated as such. ${ }^{6}$ While we must acknowledge that the modern focus on patients rather than doctors is a justified response to abused paternalism in the past, it must not be forgotten that doctors' morals exist and must be given weight. ${ }^{7}$ If, for example, a doctor objects to abortion that is not an insignificant issue and accommodating these beliefs must at least be considered. Indeed all of the arguments in favour of granting autonomy to patients, such as protecting their dignity and respecting their value and values, will apply equally to medical professionals. In short, the empathy and respect that we accord to patients we must equally accord to doctors.

Secondly, we must be careful not to 'throw the baby out with the bathwater'. As Margot Brazier has noted, we must ensure that we do not drift into a mindset that simply applies patient autonomy at the expense of all other ethical principles. $^{8}$ Thus, "[t]he domination of one among many ethical principles is disturbing", and autonomy must not be "oversold". ${ }^{9}$ Moreover, as Jonathan Montgomery has himself argued, the law has joined in the charge towards patient autonomy, and this has further risked sucking the moral aspect from medicine and medical practitioners:

the discipline of healthcare law is at risk of being transformed - moving from a discipline in which the moral values of medical ethics (and those of the non-medical health professions) are a central concern, to one in which they are being supplanted by an amoral commitment to choice and consumerism. In other words, that the morality is being taken out of medicine by legal activity. ${ }^{10}$

A similar view is expressed by Azgad Gold, who argues that it is the very paternalism that has been rejected that encouraged doctors to develop and maintain a strict moral and ethical code as a precondition of discharging their responsibilities. ${ }^{11}$ Thus,

\footnotetext{
${ }^{6}$ See, for example, N. Kenny, 'Searching for Doctor Good: Virtues for the Twenty First Century' in W. Shelton (ed), Advances in Bioethics Volume 10: Lost Virtue (Bingley: Emerald, 2006).

${ }^{7}$ Indeed, we must not forget that doctors have abused such leeway, most obviously during the holocaust. See A. Caplan (Ed), When Medicine Went Mad Bioethics and the Holocaust (New York: Humana Press, 1992).

8 M. Brazier, 'Do No Harm - Do Patients Have Responsibilities Too?' (2006) 65(2)

Cambridge Law Journal 397. See also C. Foster, Choosing Life, Choosing Death:

The Tyranny of Autonomy in Medical Law (Oxford: Hart, 2009).

${ }^{9}$ Brazier, above n. 8 at 398-9.

10 J. Montgomery, 'Law and the Demoralisation of Medicine' (2006) 26(2) Legal Studies 185 at 186.

${ }^{11}$ A. Gold, 'Physicians' "Right of Conscience" - Beyond Politics' (2010) 38 Journal of Law, Medicine and Ethics 134.
} 
[i]n the paternalistic era, the traditional moral code, which physicians shared and were educated and inspired by, was the classical commitment to heal and protect their patients. The myth of the passionately devoted physician who puts his life in danger while trying to save his patients ... reflects both the inspiration and the ideal of practicing medicine in the paternalistic era. The patient was perceived as weak and vulnerable, and therefore in need of ... protection ... [T] he physician acted on behalf of the patient as a sheltered father ... This is the other, brighter side of the paternalism that is often unremembered. ${ }^{12}$

This is certainly not to suggest either that the concept of autonomy is not of huge importance to medical law, or that the concept of autonomy is itself rigid and incapable of change. On the contrary, I would agree with Gillon that autonomy must be seen as the 'first amongst equals' of ethical principles, and this would extend to the law. ${ }^{13}$ Furthermore, the concept itself has moved far away from a simplistic notion of patients making decisions and into a rich debate that includes encompassing the interests of others, as is the case with relational autonomy. ${ }^{14}$ However, the point made by Foster in particular is that it is not a principle that must trump all others in every case. ${ }^{15}$ The danger, as identified by both Gold and Montgomery, albeit for different reasons, is that by prioritising the patient we risk marginalising and neutering the doctor and her ability for moral reflection and judgment. In order for medical conscience to flourish, then, we must allow it to be exercised in the first place. By being overly prescriptive in our demands of doctors, we do not allow them that space.

However, if we do allow this space then problems will arise when it is exploited, such as when the exercise of the doctor's conscience is one with which we disagree. A good example of this is the recent situation at Mid Staffordshire hospital, where patients were treated appallingly - and certainly not in a way that anyone would consider 'moral':

There was a lack of care, compassion, humanity and leadership. The most basic standards of care were not observed, and fundamental rights to dignity were not respected. Elderly and vulnerable patients were left unwashed, unfed and without fluids. They were deprived of dignity and respect. Some patients had to relieve themselves in their beds when they offered no help to get to the bathroom. Some were left in excrement

\footnotetext{
12 Ibid at 136.

${ }^{13}$ R. Gillon, 'Ethics Needs Principles - Four Can Encompass the Rest - And Respect for Autonomy Should be "First Among Equals"' (2003) 29 Journal of Medical Ethics 307.

14 See, for example, 0. O'Neill, Autonomy and Trust in Bioethics (Cambridge: Cambridge University Press, 2002); R. Brownsword and D. Beyleveld, Consent in the Law (Oxford: Hart, 2007); A. Maclean, Autonomy, Informed Consent and Medical Law - A Relational Challenge (Cambridge: Cambridge University Press, 2009).

15 Foster, above n 8.
} 
stained sheets and beds. They had to endure filthy conditions in their wards. There were incidents of callous treatment by ward staff. Patients who could not eat or drink without help did not receive it. Medicines were prescribed but not given. ${ }^{16}$

Here we can see the issues of conscience in the widest sense. Conscience constitutes not just decisive action or, indeed, refusing to act on the basis of one's moral code (as with conscientious objection). Rather, it includes a requirement to exercise it appropriately and to know when to do so. Clearly, that did not happen at Mid-Staffordshire. One of the key failures, as diagnosed by the inquiry into care there carried out by Robert Francis QC, was one of regulation. As can be seen in the quote below, from the executive summary, there was both a failure on the part of medical ethics and on that of the personal conscience of individuals in ensuring moral conduct. Thus,

not all boards are capable of maintaining acceptable standards or improving services at the required pace, or applying effective stewardship to the resources entrusted to them that healthcare systems regulators and performance managers exist. It is because not all professionals do live up to the high standards expected of them that we have professional regulators. ... It does not need a public inquiry to recognise that this elaborate system failed dramatically in the case of Stafford. As a result, it is clear that not just the Trust's Board but the system as a whole failed in its most essential duty - to protect patients from unacceptable risks of harm and from unacceptable, and in some cases inhumane, treatment that should never be tolerated in any hospital. ${ }^{17}$

In other words, as the italicised portions of the quote show, there are a plethora of boards that are supposed to identify and regulate poor behaviour. However, they failed to do so in this case. The situation therefore seems to be that while allowing doctors to exercise their conscience is of benefit - and the inhibition of the use of conscience a disadvantage - we must also be careful to ensure that the correct choices are made. The challenge, then, is to find a way to allow good choices to be made while eradicating the wrong ones. In other words, where conscience fails regulation must step in - a view implicitly taken by the Francis Inquiry in its conclusion, described above, that both ethics and morals failed. A particular difficulty lies in the question of whether it is a contradiction in terms to on the one hand seek to encourage doctors to exercise choice and make their own moral decisions, while at the same time being prescriptive and restrictive regarding what those decisions might be. As a first step, it is necessary to define the spaces where a doctor might exercise her conscience and where prescription is necessary or desirable.

16 Press statement by Sir Robert Francis QC, Chair of the Inquiry, downloaded at http://www.midstaffspublicinquiry.com/sites/default/files/report/Chairman\% 27s\%20statement.pdf (last accessed 6 ${ }^{\text {th }}$ August 2014), at 1.

17 Report of the Mid Staffordshire NHS Foundation Trust Public Inquiry (HC 947, 2013), above n. 1, at 8. Emphasis added. 
To this end, I would argue that there are three mechanisms by which choices might be made. ${ }^{18}$ The first of these is, indeed, the conscience or morality of the individual doctor. Clearly, any choice made under this category must be uninhibited and unrestricted. This category relates to areas where any choice made is appropriate. The second category is more inhibitive and is where the choice is made by the medical profession itself through its regulatory structures. Where the issue is ethical in nature, then, it must be made in accordance with the strictures of ethical mores. In England, this means that it must consistent with the ethical requirements outlined by the General Medical Council. ${ }^{19}$ The doctor will have to act in a certain way, or have her choice limited, if they are to adequately discharge their duties as doctors. There may be disciplinary sanctions applied by the GMC if they do not do so. The final category is the most restrictive, and is where the law demands that certain decisions are taken. Failure to comply with the legally prescribed choices may result in legal sanctions, either civil or criminal. What can be seen, then, is that only the first of the categories allows the doctor's conscience free rein - the others all, with some justification, seek to impose limits to the doctor's choice. Nevertheless, this typology is simple; the difficulty lies in determining how we appropriately place decisions into each category. Each of the categories will, briefly, be considered in turn. ${ }^{20}$

The only category where the doctor's conscience may make decisions unencumbered by any restrictions is the first one, which allows the doctor to make her own choice. While I would refer to these as 'morally autonomous' decisions, in the sense that the doctor is free to make whatever decision her conscience prefers, it is important to note that by this I do not mean that the decisions must have a moral aspect to them. Indeed, there is insufficient space here to discuss what the right moral choices might be - medical ethics books are full of such discussions and theories. ${ }^{21}$ Rather, it simply means that the individual is at liberty to make her own decision, and may make whatever decision she likes. As such, there is ultimately nothing beyond her individual morality to guide it. Such decisions are therefore pure expressions and exercises of conscience, and must, by definition, be limited in scope. Indeed, there are two principles that are vital to this category. The first is that such decisions will allow a doctor to opt out of actions, but do not provide a liberty to act with respect to competent patients. This is because in order to act the doctor must have the consent of the patient, and this, rather than the doctor's conscience, is the justification for providing treatment. The second component is that the

\footnotetext{
${ }^{18} \mathrm{I}$ am in the process of expanding on this categorisation in another piece. See C. Foster and J. Miola, 'Who's in Charge? The Relationship Between Medical Law, Medical Ethics and Medical Morality' (2015) Med L Rev (forthcoming). ${ }^{19}$ See, in general, J. Miola, Medical Ethics and Medical Law: A Symbiotic Relationship (Oxford: Hart, 2007).

${ }^{20}$ For a fuller discussion see Foster and Miola, 'Who's in Charge?', above n. 18. 21 See, for example, J. Glover, Causing Death and Saving Lives (London: Penguin, 1990), which provides an accessible outline of the moral arguments relating to various topics.
} 
decision must not place the patient in danger. Therefore the exercise of conscience is, quite properly, subject to the welfare of the patient. Examples of this category include the conscience clauses in the Abortion Act, ${ }^{22}$ and the Human Fertilisation and Embryology Act. ${ }^{23}$ These allow the clinician not to participate in treatments (abortion and assisted reproduction respectively) that may be against their personal moral codes. Both examples meet the two criteria laid down above - and indeed it is noteworthy that, in the case of the Abortion Act, the conscience clause does not apply if the health of the patient is at risk, thus explicitly applying the second component of the category. ${ }^{24}$ Therefore, we can see that this category also includes some limitations - in this case of a legal nature - thus demonstrating that the space allowed for the exercise of conscience is not infinite but confined to the principles set out above. ${ }^{25}$

The second category is where the doctor's decision is not limited by the law, but may be by the medical profession itself. I have previously referred to this as being labelled 'ethical' decisions. ${ }^{26}$ However, 'ethical' does not relate to ethical content, but instead to the question of who has overall control of the decision. Thus, in this category, the doctor's decision is limited by the requirements of the medical profession and its codes of conduct. A good example of this is the duty of medical practitioners to intervene in emergencies. English law, famously, does not contain a 'Good Samaritan' rule. Thus, nobody is forced by law to intervene to save someone else to who they have no relationship. ${ }^{27}$ However, this is not the case for doctors, who are required by their profession to help if and when they are required, such as if they pass by an accident where urgent medical care is required. ${ }^{28}$ The doctor's actions are thus prescribed by the medical profession and its ethical codes, and a failure to comply may result in sanctions administered by the profession itself. ${ }^{29}$ Thus, while a non-doctor may be able to act according to her own conscience in such circumstances, a doctor's options

\footnotetext{
${ }^{22}$ Abortion Act 1967 s.4.

${ }^{23}$ Human Fertilisation and Embryology Act 1990 s.38(1).

24 Under the Abortion Act 1967 s.4(2), the clause is suspended where a termination is 'necessary to save the life or to prevent grave permanent injury to the physical or mental health of a pregnant woman'.

${ }^{25}$ See also the case of Ms B v An NHS Hospital Trust [2002] EWCH 429, discussed by both Smith, STEVE - CAN YOU PLEASE INSERT THE TITLE OF YOUR PIECE

HERE and Foster and Miola, above n. 18. Smith also cites the case of as an example of conscience being allowed to prevail, since the doctors were permitted to transfer Ms B to another team who were willing to withdraw the treatment. I would respectfully disagree, on the basis that if one could not be found that team would have had to withdraw the treatment. I return to this below.

${ }^{26}$ See Foster and Miola, above n. 18.

27 See, for example, S. Deakin, A. Johnston and B. Markesenis, Markesenis and Deakin's Tort Law (7th ed: Oxford: Oxford University Press, 2013), at 179-81. 28 See GMC, Good Medical Practice (London: GMC, 2013), at para 26.

${ }^{29}$ For an explanation see S. Fovargue and J. Miola, 'One Step Forward, Two Steps Back: The GMC, the Common Law and 'Informed' Consent" (2010) 36(8) Journal of Medical Ethics 494.
} 
are regulated by the General Medical Council and thus more limited. Noncompliance may result in disciplinary action taken by the professional body.

The final category is where the law does take charge and, if necessary, prescribe or proscribe certain behaviours. This can therefore either come in the form of prohibiting or even, at times, demanding certain acts. Charles Foster and I used the example of the $M s B$ case as an example of this point. ${ }^{30}$ The case involved a competent woman who needed a ventilator to survive but who had decided that she wanted to die. She thus withdrew her consent to the ventilation, and asked that it be removed. The doctors treating her, however, refused to remove the ventilation, arguing that they were trained to save life rather than end it. ${ }^{31}$ We argued that

the medical profession tried to claim the issue of the desirability of Ms. B's survival as its own, by defining it as 'ethical' in nature. However the court, by recognising what it saw as the patient's right to autonomy, gave effect to that right by forcing the doctors to cease treatment. In this case, then, we can see that the law took control of a matter with ethical content and defined it as legal. ${ }^{32}$

Indeed, in that case the court did more than one of the above and thus both demanded and prohibited behaviours. It told the doctors that they could not continue treatment given Ms B's refusal of consent. The court also stated, therefore, that the treatment must be withdrawn - which would involve a positive act in reality if not in legal terms. ${ }^{33}$ Such exercises of judicial involvement are generally, as I will argue later in this article, designed to promote and protect the autonomy of the patient - a principle that has come to be seen as fundamental to both medical law and medical ethics. ${ }^{34}$

However, the Ms $B$ case is also instructive because it illustrates the fact that, sometimes, decisions can cross categories. Stephen Smith argues elsewhere in this special edition of the journal that the case is an example of the court allowing the conscience of the doctors treating Ms B to flourish, because it demanded only that Ms B's care be transferred to another team that was prepared to accede to her wishes. ${ }^{35}$ However, I would disagree with this, at least

\footnotetext{
30 Foster and Miola, above n. 18.

31 See also J. Miola, Medical Ethics and Medical Law: A Symbiotic Relationship, above n. 19 , at 168-73.

32 Foster and Miola, above n. 18.

33 The acts/omissions distinction was blurred by the House of Lords in Airdale NHS Trust v. Bland [1993] 1 All ER 821. For critical comment see E. Jackson and J. Keown, Debating Euthanasia (Oxford: Hart, 2012), at 29-33.

34 See R. Gillon, 'Ethics Needs Principles-Four Can Encompass the Rest-and Respect for Autonomy Should Be "First Among Equals"' above n.13. For a contrary view see C. Foster, Choosing Life, Choosing Death: The Tyranny of Autonomy in Medical Law, above n. 8

35 Smith, above n. 29.
} 
to a degree. My alternative view would be that, while the court did wish to allow the doctors to act within their own moral framework as much as possible, they only did so because this was possible. Indeed, given the state of the law, had there not been another treatment team willing to remove the ventilator, then the court would have had no choice but to demand that Ms B's doctors did so. ${ }^{36}$ Indeed, the scope of conscientious objection has always been limited by the patient's welfare and rights. The refusal of consent to continuing treatment by a competent patient would certainly be included in that. ${ }^{37}$ Therefore, while they did accommodate the consciences of the doctors concerned, they only did so providing that this was possible. Had it not been, the law would have had to have intervened to prioritise the autonomy of the patient over the morality of the medical staff. This would, by definition, involve forcing the treatment team to act in a way that was contrary to its stated moral position. ${ }^{38}$

These, then, are the categories within which medical law, the professional standards of the medical profession and the morality of the individual doctor have to work. Conscience relates principally to the latter category - when the decision is the doctor's to make generally unencumbered by the law or professional regulators. Nevertheless, the lines are blurred. As I note above, sometimes the law or ethical guidance might limit rather than eradicate choice. At others, it will allow choice subject to certain provisos, such as that there is another way to accommodate the patient's wishes. Nevertheless, having identified the spaces a far more difficult - if not impossible - proposition is to define what fills them. This is where the law plays the largest role, since ultimately it can, if it wishes to, claim responsibility for decisions. Equally, it may provide space by withdrawing itself from decision-making responsibility and granting it to the profession or individuals. In other words, the spaces left to professional guidance and conscience are gifts from the law and can be removed if the law wishes to do so.

A good, and perhaps the most obvious, example of this is the Bolam test that governs the reasonableness of medical conduct. ${ }^{39}$ For forty years, the courts chose to interpret the case as essentially allowing the medical profession to set

36 This would be consistent with some of the views of some of the House of Lords expressed in Airedale NHS Trust v Bland, above n. 33.

37 See, for example, J. Savulescu, 'Conscientious Objection in Medicine' (2006)

332 British Medical Journal 294; B. Dickens and R. Cook, 'The Scope and Limits of Conscientious Objection' (2000) 71(1) International Journal of Gynecology and Obstetrics 71; D. Hill, 'Abortion and Conscientious Objection' (2010) 16(2) Journal of Evaluation in Clinical Practice 344; and, for a European perspective, M. Campbell, 'Conscientious Objection and the Council of Europe' (2011) 19(3) Medical Law Review 467.

38 J. Miola, Medical Ethics and Medical Law: A Symbiotic Relationship, above n.19, chapter 7.

${ }^{39}$ Bolam v. Friern Hospital Management Committee, above n. 4. 
its own standard of care.40 It also allowed the Bolam test to expand into areas not related to matters of medical technique, such as the determination of an incompetent patient's best interests. ${ }^{41}$ However, the courts were also instrumental in reclaiming the right to make such decisions, most notably in the Bolitho case. ${ }^{42}$ The question of whether the courts have actually used this right enough is, however, another matter. ${ }^{43}$ Equally, both the common law and legislation combined, as we shall see below, to de-Bolamise best interests and, again, gain more control over decisions in that area. The same is, in theory, true of professional regulators, who can if they so wish demand that doctors act in a certain way. ${ }^{44}$ In general, then, the space for conscience is whatever is left after the law and professional regulators have determined their own boundaries. If we are to understand the role of conscience, then, we must first examine the spaces claimed by the law and professional guidance. Indeed, as I discuss below there has been a recent move away from the conscience of the individual practitioner - as Jonathan Montgomery has himself identified. ${ }^{45}$ This move, however, can both be explained and justified by looking at the role of time, and in particular the way in which medical law tends to be responsive rather than proactive.

\section{The Right Moment - Reacting to What Happened Before}

Before considering the role played by what the legal change is reacting to, however, it is first necessary to examine the importance of the definitions set out above. Medical law has, historically, been concerned with who makes decisions. ${ }^{46}$ However, the argument made here is slightly different. Rather, my argument is that identifying the spaces within which the decisions are made allows us to ask what or who makes the relevant decision. As argued above, this may be the law, the medical profession itself or the individual doctor. There may be, and indeed is, room for significant debates regarding the adequacy, or lack of it, of each of the categories in ensuring that good moral decisions are made. ${ }^{47}$

40 See M. Brazier and J. Miola, 'Bye Bye Bolam: A Medical Litigation Revolution?' (2000) 8(1) Med L Rev 85 and A. Grubb, 'Contraceptive Advice and Doctors - A Law Unto Themselves?' (1988) 47 Cambridge Law Journal 12.

${ }^{41} \mathrm{~F} v$ West Berkshire Health Authority [1990] 2 AC 1.

${ }^{42}$ Bolitho v City \& Hackney Health Authority, above n. 4.

43 R. Mulheron, 'Trumping Bolam: A Critical Legal Analysis of Bolitho's "Gloss"' (2010) 69(3) Cambridge Law Journal 609.

44 See, for example, Fovargue and Miola, above n. 29.

45 J. Montgomery, 'Law and the Demoralisation of Medicine', above n. 10.

46 This is particularly prevalent in the work of such influential medical lawyers as Ian Kennedy. See, for example, I. Kennedy, The Unmasking of Medicine (London: Flamingo Books, 1983) and, in particular, the chapter 'What is a Medical Decision?' in I. Kennedy, Treat Me Right: Essays on Medical Law and Ethics (Oxford: Oxford University Press, 1991).

${ }^{47}$ For the (in)adequacy of the law see S. McLean, Old Law New Medicine: Medical Ethics and Human Rights (London: Pandora Press, 1998), for that of medical ethics see J. Miola, Medical Ethics and Medical Law: A Symbiotic Relationship, above $\mathrm{n} 11$; and for the inadequacy of relying on the individual doctor's 
Nevertheless, the categorisation set out above is intended to determine which entity is tasked with decision-making power.

Over the decades, medical law has undergone a transformative process. The general direction was initially for the law to cede control of decision-making, trusting the medical profession and individual practitioners within it to make decisions. This led Sheila McLean to argue that the law was abrogating its duty to protect patients from doctors. ${ }^{48}$ The Bolam test, as mentioned above, both galvanised and catalysed this abrogation of responsibility through both a narrow interpretation of the test itself and a widening of its application. ${ }^{49}$ It should be noted, however, that the abrogation tended to be to the medical profession as a whole rather than individual practitioners. ${ }^{50}$ The reluctance to trust the conscience of individual practitioners can be traced to the actions of Nazi doctors during the Second World War. ${ }^{51}$ However, at times the conscience of individual practitioners has unwittingly been allowed to be paramount. ${ }^{52}$ This is because, as I have argued before, the law's erroneous assumption that the medical profession's ethics is designed to regulate in a quasi-legal manner allows slippage from professional control to individual choice by a medical practitioner. ${ }^{53}$

More recently, however, the mood of medical law has changed, and it can be argued that the last two decades have seen a general shift away from the law's previous reticence to become involved and towards a more explicit interventionism. Essentially, the law has sought to reclaim the ground that it had previously surrendered. Indeed three examples, all emanating from the mid1990s, provide a taste of the law's desire to recapture decision-making authority and thus remove it from the conscience of the individual practitioner or the medical profession. The first is the decision of the House of Lords in the case of Bolitho mentioned above. ${ }^{4}$ The facts of the case, and indeed the details of the decision, are not important to this article, and have been examined elsewhere. ${ }^{55}$

conscience see R. Lifton, The Nazi Doctors: Medical Killing and the Psychology of Genocide (New York: Basic Books, 1986) and A. Caplan, When Medicine Went Mad: Bioethics and the Holocaust, above n. 7.

48 S. McLean, Old Law, New Medicine, above n. 47 at 2.

${ }^{49}$ See M. Brazier and J. Miola, 'Bye Bye Bolam: A Medical Litigation Revolution?', above n. 40.

50 See J. Miola, 'Medical Law and Medical Ethics: Complementary or Corrosive?' (2004) Med L Int 251.

51 See, for example, Lifton, The Nazi Doctors, above n. 47 and Caplan, When

Medicine Went Mad, above n. 7.

52 J. Miola, 'Medical Law and Medical Ethics: Complementary or Corrosive?', above n.30.

53 Ibid, and see also J. Miola, Medical Ethics and Medical Law: A Symbiotic

Relationship, above n. 19.

54 Bolitho, above n. 4.

55 See Brazier and Miola, above n. 40 and, for a more contemporary analysis, R. Mulheron, 'Trumping Bolam: A Critical Legal Analysis of Bolitho's "Gloss" above n. 43. 
What is important to us that, previously, the Bolam test had operated in a way that allowed the medical profession to set its own standard of care. ${ }^{56}$ As long as there was a body of medical opinion that might have done as the defendant doctor did, then no court could find her to have acted unreasonably (and therefore negligently). ${ }^{57}$ What the House of Lords did in Bolitho, albeit tentatively and with some caveats, was to make the courts, rather than the medical profession, the ultimate arbiters of reasonableness. Thus,

the court is not bound to hold that a defendant doctor escapes liability for negligent treatment or diagnosis just because he leads evidence from a number of medical experts who are genuinely of the opinion that the defendant's treatment or diagnosis accorded with sound medical practice. ... [I]f, in a rare case, it can be demonstrated that the professional opinion is not capable of withstanding logical analysis, the judge is entitled to hold that the body of opinion is not reasonable or responsible. ${ }^{58}$

As mentioned above, ultimate decision-making responsibility was removed from the medical profession as a whole and restored to the courts. The second example is related to that one: the definition of 'best interests'. Patients who lack capacity to make their own decisions can receive medical treatment despite their inability to consent if that treatment is in their best interests. In the House of Lords case of $F \mathrm{v}$ West Berkshire Health Authority in 1989, this definition was Bolamised - in other words, it was one for medical professionals to make (given that this was before Bolitho). However, a process of change on two fronts succeeded not just in de-Bolamising the concept but actually encouraging the patient, rather than her medical interests, to be put at the heart of the matter. Thus, the common law began to change as judges realised that the concept of best interests must include considerations much wider than what is medically best for the patient. ${ }^{59}$ However, legislative change was also afoot, with a report published by the Law Commission in 1995 making clear its determination to distinguish between what is best for the patient and what is medically most appropriate, as well as the fact that not even the medical profession supported such an approach any longer:

The apparent conflation of the criterion for assessing complaints about professional negligence with the criterion for treating persons unable to consent has been the butt of vehement criticism. No medical professional or body responding to Consultation Paper No 129 argued in favour of retaining such a definition of 'best interests'. Many were extremely anxious to see some clear and principled guidance given as to what 'best

\footnotetext{
56 This was, moreover, explicitly acknowledged by the judiciary. See, for example, the comments of Lord Scarman to this effect in the House of Lords in Sidaway v Board of Governors of Bethlem Royal Hospital [1985] AC 871 at 882. 57 See Maynard v West Midlands Health Authority [1984] 1 WLR 634.

58 Bolitho, above n. 4 at 241.

${ }^{59}$ See, for example, Butler-Sloss LJ in Re SL (Adult Patient: Sterilisation) [2000] Lloyds Rep Med 339; Re A (Medical Treatment: Male Sterilisation) [2000] 1 FCR 19.
} 
interests' might involve. The British Medical Association, for its part, supported our provisional proposals for statutory guidance 'without reservation'. ${ }^{6}$

The result - s.4 of the Mental Capacity Act 2005 - has introduced a test that is supposed to balance the welfare of the patient with her right to autonomy. The test thus contains objective welfare considerations, as well as a 'substituted judgment' approach that asks what the patient would have wanted had she had the capacity to make her own decision. ${ }^{61}$ The balance is not always easy to achieve correctly, but at the same time at least the patient's own wishes have to be considered. ${ }^{62}$ Indeed, the Code of Practice that accompanies the Act itself states that the Act aims to be a 'statutory framework for people who lack capacity to make decisions for themselves, or who have capacity and want to make preparations for a time when they may lack capacity in the future'.63. This is essentially a recognition that such decisions are not intrinsically 'medical' in nature. Rather, they relate to matters outside of technical medical skill such as how much to take the patient's views into account, and those of her family. How much weight should be given to various alternative options? To use the example of sterilisation - which many of the cases regarding best interests related to should the patient be sterilised or should an IUD (which would have to be changed periodically) be fitted? With respect to end of life treatment, should an adult in a minimally conscious state be kept alive? All of these questions cannot be divorced from moral and ethical questions that will, at times, require the exercise of conscience. The 2005 Act seeks to remove ultimate decision-making authority from doctors with respect to these decisions.

The final example of the law's direction is that of the Human Tissue Act 2004. Prior to the 2004 legislation, the law surrounding the removal, storage and use of human organs and tissue was extremely permissive. ${ }^{64}$ The Human Tissue Act 1961 had contained a number of flaws that had the effect of essentially allowing medical professionals to do what they liked. ${ }^{65}$ In particular, there were no real consent provisions, and control over the body of a dead person resided with whoever had 'control' over it (although who this might be was never explained in the Act). ${ }^{66}$ When a patient died in hospital, this was assumed to be the hospital, who could therefore authorise the removal and storage of organs, or their use for research purposes, irrespective of the known wishes of the patient or her

${ }^{60}$ Law Commission, Mental Incapacity (Law Com 231, 1995), para 3.26.

61 See, for example, the Canadian case of Re Eve (1987) 31 DLR (4th) 1.

62 J. Coggon, 'Anorexia Nervosa, Best Interests, and the Patient's Human Right to

a "Wholesale Overwhelming of her Autonomy"' (2014) 22(1) Med L Rev 119,

discussing the case of $A$ Local Authority v. E [2012] EWHC 1639 (COP).

63 DCA, Mental Capacity Act 2005 Code of Practice (TSO, 2007), at

https://www.justice.gov.uk/downloads/protecting-the-vulnerable/mca/mca-

code-practice-0509.pdf (last accessed 1st September 2014).

64 D. Price, 'From Cosmos and Damien to Van Velzen: The Human Tissue Saga

Continues" (2003) 11(1) Med L Rev 1.

65 Ibid.

${ }^{66}$ Human Tissue Act 1961, s.1(2). 
relatives. ${ }^{67}$ Moreover, despite this laxity, the Act did not even contain any sanctions for non-compliance, and it was even unclear whether the Act was intended to form part of the civil or criminal law. ${ }^{68}$ The 2004 Act explicitly sought to correct these problems. Indeed, in announcing the legislation the Secretary of State for Health focussed specifically on the importance of consent and sanctions:

... the law will be changed to enshrine the concept of informed consent. The existing law in this area has become outdated. The Human Tissue Act 1961 does not even contain penalties for breaches of its provisions. The law has ill served bereaved parents in our country and causes confusion for staff. It must be changed. ${ }^{69}$

The new Act therefore has consent as its basis, and prescribes criminal sanctions (including custodial sentences) to punish breaches. ${ }^{70}$ In short, medical conduct is far more regulated than it was under the 1961 Act.

The three pieces of legal change outlined above share some common factors. First, in all three examples the law consciously and deliberately altered the category of decision-making from one where the profession and its guidelines ruled, to the one where the law took responsibility. It is noticeable that in all three cases decision-making authority seems, before the changes described, to fit into the category of professional rather than personal decisions. Thus, conscience had already been marginalised unless one considers professional guidelines to be the corporate conscience of the medical profession. ${ }^{71}$ I should be clear that I am not here ascribing 'conscience' to corporations or hospitals. ${ }^{72}$ Rather, I am arguing that in regulated professions such as exists in medicine professionals must follow the codes and mores of the industry or they might be prevented from practicing. Where the decision is ethical in nature, this will constitute the profession taking an ethical position, which effectively constitutes the exercise of

67 If this is not was intended, it certainly happened as acknowledged by the MDU - see J. Lucas, 'Doctors' Duties Under the Human Tissue Act' (2013), http://www.themdu.com/guidance-and-advice/journals/mdu-journal-april2013/doctors-duties-under-the-human-tissue-act (last accesed 2nd October 2014).

68 J. Miola, "Law, Ethics and Human Tissue Research - Integration or Competition?" in K. Beier and C. Lenk (eds), Human Tissue Research - A European Perspective on the Ethical and Legal Challenges (Oxford: Oxford University Press, 2011)

${ }^{69}$ Hansard, 30th January 2001 (2001). Available at:

http://www.publications.parliament.uk/pa/cm200001/cmhansrd/vo010130/d ebtext/10130-06.htm (last accessed 2nd September 2014). Emphasis added. ${ }^{70}$ Human Tissue Act 2004 s.5(7).

${ }^{71}$ I would certainly argue that this would be a fair comment to make - see J. Miola, Medical Ethics and Medical Law: A Symbiotic Relationship, above $\mathrm{n} 19$.

72 Although it should be noted that some, such as Bernard Dickens, do so. See B. Dickens, 'Conscientious Objection: A Shield or a Sword?' in S. McLean (Ed), First, Do No Harm: Law, Ethics and Healthcare (Farnham: Ashgate, 2006). 
conscience on the part of that profession. A good example is the requirement that health professionals have a duty to refer patients for abortions. ${ }^{73}$ The Supreme court has just held that it is permissible for this to be a professional requirement. ${ }^{74}$ I would here entirely agree with Cook and Dickens that where a profession has such requirements, the conscience of the individual is marginalised. ${ }^{75}$ Nevertheless, there is a clear shift in category for each of the examples in the direction of the law.

But why did this occur? It is obvious that such things do not happen in a vacuum. Indeed, in each of the examples above one can see that the change in the law was a response to either a specific event or a change in mood. The factor linking them all is that the response sought to limit medical decision-making outside of issues of technical expertise and thus the exercise of their consciences rather than their medical expertise. In the case of Bolitho, Lord Woolf, then the Master of the Rolls, wrote a piece a short time later explaining why the change in emphasis was needed.76 In it, he argued that there had been a culture of deference amongst judges, and that this had now changed. The decision of the House of Lords in Bolitho was, in essence, the manifestation of that change in attitude. It had occurred organically, but was perhaps inevitable. If nothing else, judges were simply following sustained academic criticism of this overt deference by some of academic medical law's most influential writers. ${ }^{77}$

Similarly, the change in the definition of best interests was driven by the same change in attitude at around the same time. Indeed the legislative road to the Mental Capacity Act has been well documented, and as I argued above, one of the catalysts for the legislation was a general view noted by the Law Commission that 'best interests' and 'medical interests' had become too synonymous. ${ }^{78}$ What tends to be forgotten, particularly since the Mental Capacity Act has come into force, is that the common law had also engaged in a similar process, and indeed by the time the Mental Capacity Act was close to being passed many of the provisions of s.4 had essentially already found their way into the common law definition. ${ }^{79}$ This also occurred shortly after Bolitho, and can also be seen as judges taking the initiative to change the direction of the law, and also to further de-Bolamise medical law.

\footnotetext{
73 See Doogan and Wood v. NHS Greater Glasgow and Clyde Health Board [2013] CSIH 36, and Mary Neal's excellent casenote: M. Neal, 'The Scope of the Conscience Based Exception in S.4(1) of the Abortion Act 1967' (2014) 22(3) Medical Law Review 409. The Supreme Court has just affirmed the decision of the Scottish court: Greater Glasgow Health Board v. Doogan [2014] UKSC 68. 74 Ibid.

75 See Dickens and Cook, above n. 37.

${ }^{76}$ Lord Woolf, 'Are the Courts Excessively Deferential to the Medical Profession?' (2001) 9 Med L Rev 1.

77 See, for example, Kennedy, Treat Me Right, above n. 46.

78 See Law Commission, Mental Incapacity above n. 60 at para 3.26.

${ }^{79}$ Re A (Medical Treatment: Male Sterilisation) and Re SL (Adult Patient: Sterilisation) [2000], above n. 59.
} 
The Human Tissue Act 2004, however, was conceived as a specific response to a scandal that highlighted the deficiencies in the previous legal framework. During the inquiry into paediatric heart surgery at Bristol Royal Infirmary (BRI) between 1984-1995, chaired by Professor Sir Ian Kennedy, it was revealed that at BRI organs had been taken from the dead babies and infants without the knowledge or consent of their parents. ${ }^{80}$ As a consequence, some parents were particularly upset to have discovered that they had buried their children without some of their organs, including their hearts, which had been kept for research purposes. Not surprisingly, this information caused a scandal. ${ }^{81}$ Worse was to come, when it was discovered that such practices were rife not just at Alder Hey Children's Hospital in Liverpool, but indeed all over the country. ${ }^{82}$ There was no legal method available to punish what the general public saw as wrongdoers indeed, they had broken no laws. The hospitals were in 'lawful possession' of the children's bodies, and it was thus for them to decide on whether organs should be removed and retained. The Human Tissue Act 2004 was thus a direct response to this medical behaviour and the perceived inadequacy of the law in protecting patients. In essence the law reclaimed the decision-making authority that it had previously granted the profession, and in effect (albeit inadvertently) changed the decisions regarding organ removal and retention from one governed by the medical profession to one governed by the law.

All of these developments either arose or were catalysed during the mid-1990s, as a result of a specific event, a mood change on the part of the judiciary or a combination of the two. It might also be argued that the mood of judges may have been hardened in the wake of a slew of scandals that enveloped the medical profession around the turn of the millennium. These included doctors who deliberately killed their patients, gynaecologists carrying out unnecessary operations to a poor standard, indecent assaults on women by doctors and others lying about their qualifications. ${ }^{83}$

As mentioned above, these scandals had also been accompanied by an atmosphere within academic medical law that emphasised the law's bias towards medical professionals and away from patients. It can be said, then, that this was a perfect storm to encourage a change of legal focus, and this is what occurred. What can be seen, then, is that the change in the pattern of the law relates to time. At a specific moment - the 10 year period between 1990-2000 covers virtually all of the events considered above - everything aligned in such a way as to make reform of the law likely if not inevitable. Indeed, the law can thus be said to be reactive: if there is change it is generally, but not always, as a

${ }^{80}$ Learning From Bristol: The Report of the Public Inquiry into Children's Heart Surgery at the Bristol Royal Infirmary 1984-1995 (Cm 5207, 2001).

81 See D. Price, 'From Cosmos and Damien to Van Velzen', above n. 64.

${ }^{82}$ K. Liddell and A. Hall, "Beyond Bristol and Alder Hey: The Future Regulation of Human Tissue” (2005) 13(1) Med L Rev 170.

83 These examples, and others, are identified and discussed in M. Dixon-Woods, K. Yeung and C. L. Bosk, 'Why is UK Medicine No Longer a Self-Regulating Profession? The Role of Scandals Involving "Bad Apple” Doctors' (2011) Social Science and Medicine 1. The descriptions of the scandals can be found at page 3. 
response to events rather than through its own initiative. Sometimes, such as with the Human Tissue Act 2004, it is a reaction to a very specific event. But it can also refer to a change in mood, particularly when change shift is brought about by a series of other occurrences. In the case of medical law, the scandals can very much be seen as at the very least facilitators of the law's change of direction, which can be seen to have changed the emphasis from doctors' privileges to the rights of patients. Given this change of mood, it was almost inevitable that the exercise of conscience on the part of doctors would be curtailed. If the new mantra became 'patients' rights', it was natural that it would be themselves that would make decisions relating to them. Moreover, it did not help that, particularly in the case of the Human Tissue Act, the change was deemed necessary because of an obvious failure of medical conscience. The mood had changed, it coincided with a lack of trust in medical decision-making, and there were reasons for that.

\section{The Effect on Conscience}

Needless to say, such legal changes have an effect on the ability of medical professionals to allow their own moral values to influence their decisions. Even their regulation itself is different, with the GMC in particular changing from being a body that was seen as representing doctors to one that is almost independent of them given its role as a regulator. ${ }^{84}$ If a patient has a 'right' to something - be it information about risks and alternatives, or even a more basic right to autonomy preventing interference with her body without consent - then the doctor's options are limited, at least to a degree. Sometimes, this can be a positive development. A good example of this would be informed consent. Before the law changed to prioritise patient autonomy, it allowed paternalist medical professionals to withhold information about risks that they felt might cause patients to panic and refuse consent to procedures that the doctors felt would be in their best interests. The rejection of this approach, indeed, formed the basis of the law's change in direction. Thus, as Lord Scarman made clear in the House of Lords,

The profession, it is said, should not be judge in its own cause; or, less emotively but more correctly, the courts should not allow medical opinion as to what is best for the patient to override the patient's right to decide for himself whether he will submit to the treatment offered him. ${ }^{85}$

While we might all agree with the sentiment expressed by his Lordship, as mentioned above it is undeniable that it constitutes a restriction of the doctor's ability to use her conscience to decide how much information to provide to her patient. Indeed, the law has developed in such a way as to make the law the ultimate arbiter, so that it can take control itself and, in its view, better protect

\footnotetext{
${ }^{84}$ For a recent example see H. Williams, C. Lees and M. Boyd, The General Medical Council: Fit to Practice? (Civitas, 2014). The report finds that the GMC has tried to 'reinvent its image' in the light of medical scandals (at page 7).

85 Sidaway v Board of Governors of Bethlem Royal Hospital, above n. 56 at 882. Emphasis added.
} 
patient autonomy. ${ }^{86}$ This means that the law will inevitably become more involved in decision-making, as it identifies patients' 'rights' and protects them from individual doctors and, if necessary, the medical profession as a whole. This has been identified by Thomas Faunce who has argued that, in a legal landscape where human rights are seen as more and more important, medical ethics may find itself subsumed and redundant. ${ }^{87}$ Indeed, patients have a right under the European Convention on Human Rights to be free from torture and degrading treatment, to a private and family life and to freedom of thought, conscience and religion amongst others. ${ }^{88}$ These necessarily impact on medical treatment - surgery can be torture in some circumstances, the right to privacy is breached if the patient's autonomy is not respected and if the patient has, for example, a religious objection to treatments such as blood transfusions then this must also be respected.

The doctor's own views and those of the profession must, by definition, bend to these rights, and it behoves the law to protect them. For some, such as Montgomery, this is not a welcome development, as I noted at the beginning of this article, 89 it is difficult to argue with Montgomery's diagnosis of the current situation - if the law exists to uphold the 'rights' of patients, then it is almost inevitable that they become consumers exercising choice. ${ }^{90}$ The moral reflection and conscience of medical professionals, and indeed of the medical profession as a whole, is sacrificed to a market where, in essence, anything goes. ${ }^{91}$

Moreover, this imperative for the law to intervene will necessarily result in more responsibility on the law to make ethical decisions itself. This, of course, begs the further question of whether the law is actually equipped to do so. Instinctively, Faunce's suggestion that human rights standards may provide a substitute for medical ethics is seductive and suggests that the law may well provide an answer. Indeed, there might be several advantages to such an approach. First, the human rights standards would concentrate on patients' rights rather than doctors' duties. If the law will inevitably respond to scandals and react to medical paternalism, then this must be seen as a positive. Secondly, the law is used to acting as a decision-maker. In fact, one of the criticisms that can be laid at the door of medical ethics as a mechanism for ensuring that only

86 See, for example, Chester v. Afshar [2004] UKHL 41.

87 T. Faunce, 'Will International Human Rights Subsume Medical Ethics? Intersections in the UNESCO Universal Bioethics Declaration' (2005) 31(3) Journal of Medical Ethics 173. For a fascinating contrary view that argues that the two need each other to operate effectively see R. Ashcroft, 'Could Human Rights Supersede Bioethics?' (2010) 10(4) Human Rights Law Review 639. 88 Under Articles 3, 8 and 9 respectively.

89 J. Montgomery, 'Law and the Demoralisation of Medicine', above n. 10 at 186.

${ }^{90}$ For an analysis of Article 9 of the European Convention on Human Rights (freedom of thought, conscience and religion) in relation to conscientious objection in the medical setting see M. Campbell, 'Conscientious Objection, Health Care and Article 9 of the European Convention on Human Rights" (2011) 11(4) Medical Law International 284.

${ }^{91}$ For a fuller discussion see Foster and Miola, above n.18. 
good moral decisions are made by doctors is that it has become increasingly reflective rather than directive. ${ }^{92}$

However, there are also some other reasons to believe that things might not be quite so straightforward. To begin with it has to be noted that, despite the law's recent apparent conversion to patient protection, it has not always had a stellar record in this area. On the contrary, it might well be said that the period since the mid 1990s is the only one in which medical law has actually been willing to question medical practitioners. Thus, as recently as 1999 Sheila McLean was writing that

No matter the quality of medicine practised, and no matter the doubts of doctors themselves about the appropriateness of their involvement, human life is increasingly medicalised. In part, this is the result of the growing professionalism of medicine, in part our responsibility for asking too much of doctors. In part, however, it is also because the buffer which might be expected to stand between medicalisation and human rights namely the law - has proved unwilling, unable or inefficient when asked to adjudicate on or control issues which are at best tangentially medical. ${ }^{93}$

In other words, if we say that we want the law to take more control, what we are actually saying is that we like the current approach taken by judges. Of course, should this change we would regret our decision - we should therefore be careful what we wish for. Indeed, we must ask ourselves whether it is the law as a mechanism that we support, or merely its present stance towards patients' rights. The former offers far more permanence than the latter.

Another factor to consider is whether the law is actually willing and able to engage in the sort of ethical reflection that we expect from the conscience of individual doctors and the medical profession in general terms. For those who think that the law's change in focus is, in general, a positive development (and this author would count himself amongst them), it is also important to examine the way in which it does engage in ethical debate. A closer look, however, reveals that it has a far from perfect record in the area. John Coggon and I have argued that, in the context of the law relating to risk disclosure, the law's ethical thought has been lacking, and that it has confused the concept of liberty with that of autonomy. ${ }^{94}$ In short, we argued that the law's conflation of the freedom to make decisions with autonomy was overly simplistic and did not focus on many of the elements that would be necessary for a truly autonomous choice, such as communication to ensure adequate understanding of the issues, and perhaps even dialogue and debate. It is noteworthy that this approach by the law does not reflect much of the scholarship by academic lawyers and ethicists, where

\footnotetext{
92 See J. Miola, Medical Ethics and Medical Law: A Symbiotic Relationship, above n.19.

93 S. McLean, Old Law, New Medicine, above n. 47 at 2.

94 J. Coggon and J. Miola, 'Autonomy, Liberty and Medical Decision-Making' (2011) 70 Cambridge Law Journal 523.
} 
there has been much discussion of precisely these issues. ${ }^{95}$ However, and perhaps critically, the legal standard can also be seen to be below the standard set by medical ethics. Thus the General Medical Council's guidance to doctors does contain many of these important elements of autonomy, and it might well be argued that it would constitute a better protection of autonomy than the law does. ${ }^{96}$ To this end, the law's reclamation of ultimate authority from the professional standard might be mourned rather than celebrated. ${ }^{97}$

\section{Making Good Decisions - A Role for Whose Conscience?}

The law in England has undergone a significant change in emphasis. While 20 years ago medical law looked at the duties of doctors, and largely trusted them to set their own standards, this has now changed. Today, medical law tends to look at the rights of patients, and is prepared to be far more interventionist in order to be seen to protect them. By definition, this has implications for medical practitioners' ability to use their own consciences to make moral decisions. However, two points should also be noted about the classifications that I identify above - legal, 'ethical' and morally autonomous decisions. First, even when the law acted in a manner that was subservient to the medical profession, it was still far more likely to defer authority to the medical profession rather than the conscience of individual doctors. Thus, while it might be said that medical practitioners were able to exercise a significant degree of moral decisionmaking, this was assumed by the law to be done within the confines of a stringent set of professional codes that would regulate it effectively. Secondly, some issues can cross the boundaries of each category. In other words, in some areas of medical law the law might allow the doctor's conscience to prevail to an extent, and only intervene in certain scenarios. A good example of this would be that provided at the beginning of this paper regarding the conscience clause contained in the Abortion Act 1967: a doctor may refuse to participate in a termination (which would allow her conscience to govern the decision) unless the mother's life or health may be at serious risk, in which case the law will intervene and require participation (thus making the law the final decisionmaker). This is only right and proper, as we ought to seek to allow doctors to use their own moral judgment as much as is possible without compromising the rights of patients.

Nevertheless, as Montgomery has highlighted, the law's trajectory towards interventionism carries the risk of strangling this exercise of moral judgment by

\footnotetext{
95 See n. 14 above.

96 By 'better' I mean both more stringent and more actually respectful of autonomy. See J. Miola, 'On the Materiality of Risk: Paper Tigers and Panaceas' (2009) 17 Medical Law Review 76. This is not to say that the GMC guidance is perfect. For a critical appraisal see, for example, S. Fovargue and J. Miola, 'One Step Forward, Two Steps Back: The GMC, Common Law and "Informed" Consent' above n. 29.

${ }^{97}$ Although, of course, this analysis only lasts so long as the ethical guidance remains more respectful of autonomy than the law does. See Miola, 'On the Materiality of Risk', ibid.
} 
doctors. A further consequence of this, beyond the (amoral) consumerism that he rightly argues may become prevalent, is that the law itself will take increased responsibility for making these moral decisions. In other words, the exercise of conscience will be taken away from medical professionals and the profession as a whole and given to the law. This, of course, begs the question of whether the law is equipped to assume such responsibility. Indeed, if it is to take back the decision-making authority that it abrogated to the medical profession it should at least be sure that it will be better than what it is replacing. As I argue above, the common law's record of ethical reasoning is less than exemplary. Indeed, it might be said that there is no evidence that judges even realise that they are making ethical decisions. ${ }^{98}$ Again, there is a conversation to be had about these issues that has yet to occur, and we are thus acting before thinking.

Yet it must also be said that there is little in the way of criticism of the law's new approach. I would argue that this is not because commentators feel that the law is uniquely qualified or the most appropriate mechanism for making such ethical decisions. Rather, I believe that the reason for this is that is that the law's current approach happens to match that preferred by those of us who felt that its previous deference was misguided. However, given that it is a reaction to events in the form of scandals, this can easily change if there are further events that suggest that the law ought to change course again.

But will this change in judicial attitude prevent another Shipman or Stafford? In short, no. At best, the law can seek to inculcate a culture where doctors understand that 'patients' rights' are the priority, and that if anything their own consciences must come second to that. However, it must also be said that the law's interventionist approach is likely to do little to improve the conscience of individual doctors or indeed the medical profession as a whole. Perhaps ironically, that must come from within rather than being imposed from outside. In this sense, Montgomery's concern that the law's involvement will not cement a strong moral code on doctors and their profession but instead risks sucking it out is both astute and a possibility. Nevertheless, the changes in the law's direction have not occurred in a vacuum, and failures in medical conscience have contributed to the process. It is simply not feasible or right to revert to the excessive deference that doctors once enjoyed in relation to the law.

I realise that what I have provided here is more questions rather than answers. What is really needed is a comprehensive discussion regarding when individuals, the profession and the law ought to be the final arbiters in decisions with ethical content. This will be difficult, and it might even be the case that there is no way that a generalised set of principles can be found to reach an answer. However, what can be said is that the current, ad hoc, system of reaction is unsatisfactory and leaves us a hostage to fortune to whichever decision-maker we happen to favour at the time.

98 Ibid. 